\title{
The Plight of a Nation without a State: An Analysis of the Struggle of Kurds for an Independent State
}

\author{
Amna Mahmood*1, Fouzia Munir ${ }^{1} \&$ Sharin Shajahan Naomi ${ }^{2}$ \\ 1. Department of Politics and IR, International Islamic University, Islamabad, Pakistan. \\ 2. Department of Gender Studies, Asian University for Women, Bangladesh.
}

\begin{abstract}
Struggle of the Kurds for an independent state can be considered to be one of the most challenging and most underestimated issue in the political analysis of Middle East. Kurd is the fourth largest ethnic group in this region with an estimated populace of 35 to 40 million who are dissipated among four states Turkey, Iraq, Syria and Iran separately. This study intends to examine the origin of Kurds, their political struggle, the factors that compelled Kurdish Regional Government (KRG) of Iraq to conduct referendum for Independence and reaction of all the four countries who share Kurdish population. By adopting exploratory and explanatory approaches and utilizing primary as well secondary data, it has been found that Kurdish struggle and its outcome have been influenced by multiple complex factors which led their conflict to an unresolved state. Our analysis concluded that the states need to realize that suppression of ethnic identities and voices of Kurds might appear to be solution for short time, but not in the long run for promoting peace and regional stability in the Middle-East.
\end{abstract}

Keywords: Kurdistan, Non-state Nation, Referendum, Ottoman, Iraq, Syria, Turkey, Minorities, Genocide, Struggle for Independence.

\section{Introduction}

The Kurds, who in numbers are between 35 to 40 million, are the largest ethnic group without state (BBC, 2017). As tribally structured nation, they remained in the Middle East since old times with root of the Iranian branch of Indo-European family who settled in the, Zagros and Taurus Mountains for the most part during the second thousand years BC (McDowall, 2004). The Middle East has been subject to faulty and questionable border demarcations in the post First World War scenario that led to more conflict and chaos. Kurdish issue can be considered to be one of the most challenging conflict in the region in terms of intensity and long time period of Kurd's struggle, and having no apparent solution. The modern history of Kurdish people has been full of betrayal, abuse, war, and the struggle for national liberation. After First World War and the disintegration of Ottoman Empire, the victorious western alliance made provision for a Kurdish state in Treaty of Sevres 1920 (Durham, 2010). Article 62 of this treaty provides the Kurds independence and Article 64 permits probable independence (Durham, 2010). Expectations for independence were broken when the Treaty of Lausanne 1923 was signed setting the boundaries of modern Turkey. There was no provision for a Kurdish state in that treaty. As a result, Kurds were left with minority status in their respective countries. The Ottoman Kurdistan partitioned between Turkey and two Arab countries Syria and Iraq, which 
were under French and Britain command separately. Since then, Kurds in their respective countries have been engaged in battle and continuous political struggle to achieve independence and autonomy. The political aspiration of Kurds for right to self-determination and their resistance to nationalization have been central to the concern for Kurds (Bayat, 2008). The Kurdish Regional Government in Iraq was established in 1991.

Kurdistan in Iraq has been an autonomous region since 1992. It assumed a quasi-state when United State along with Britain and France established no fly zone in the northern Iraq. Since then, the Kurdish Regional Government (KRG) enforced de facto status of a state. Today KRG enjoys all the components of a sovereign state including having its own territory, population, government and constitutional rights to conduct foreign relations. During the period of first Iraqi republic from 1921 to 2003, Kurds were gassed, bombed, ethnically cleansed and displaced from their homes. During the time of second republic, they were deprived of adequate budget to manage their affairs and their political rights were violated. Additionally, the rise of ISIS (Islamic State of Iraq and Syria) created security challenges to the Kurds on the northern border. Their limited constitutional sovereignty did not allow them to get help from other countries. As a result, Kurds did not want being part of one Iraq.

In June 2014 ISIS (Islamic State of Iraq and Syria) campaign in the Northern Iraq led to collapse of Iraqi military dominance and KRG emerged as a powerful actor in the region. The Kurdish Regional Government (KRG) conducted a referendum on 25 September 2017. The overwhelming vote from that referendum in favour of independence from Iraqi central government provoked extreme negative response and apprehension for more conflict within the Middle Eastern region. The purpose of this paper is to understand the complexities around struggle of the Kurds for an independent state. This paper traces the origin of the Kurds, their political struggle in Iraq, analyse the factors that compelled KRG to conduct Independence Referendum and reaction of the countries who share Kurdish population including Turkey, Iran and Syria. Our analysis included responses of regional and international actors to the conflict on an independent state for the Kurds and why the conflict is still unresolved.

\section{Literature Review}

A number of historians have presented different perspectives regarding the origin and history of Kurds. The most influential and first study was conducted by Sharif Khan Bidlisi in his book titled "Sharafnamah" (a history of Kurds in 1597) (Bidlisi, 2005). The book provided a detailed overview of the origin of Kurds, their language, religion, and social structure. Among modern historians, David McDowall provided comprehensive historical account of the Kurdish society in Middle East (McDowall, 2004). He traced the problems being experienced by the Kurds back to the policies of the Ottoman and Iranian empires which they had adopted towards their Kurdish populations in the seventeenth and eighteenth centuries. He provided useful insights in understanding the internal and external dynamics of Kurdish question (McDowall, 2004). Moreover, Martin Van Bruinessen's work, "Agha, Shaikh and the State" (1992) is one of the most influential historical and sociological studies initiated on the Kurds. This work examined the social and political structures of Kurdistan and the role of tribal loyalties within Kurdish societies (Bruinessen, 1992).

Kurdistan - the place that is known for ethnic Kurds comprises the geographical zones in the Middle East where the boundaries of Iraq, Turkey, Syria, and Iran meet. Before the World War 
I, Kurdistan was separated between the Ottomans and the Persian territories. Subsequently, after the World War I Kurdistan was broken into four diverse nation-states (Gunter,2003). Chaliand (1980) described that at the end of colonization the Kurds came under the 'rule of four' (Turkey, Iraq, Iran and Syria). Moreover, the genocidal and ethnocide policies pursued by the states involved threatened the very existence of the Kurds, especially in Turkey and Iraq (1980). Kurd's history has been written by constant revolts and bloody repression, massacres, deportation and frequent uprisings. In Iraq the Kurdish Regional Government operated as a defacto Kurdish state since the implementation of a United States led no fly zone in 1991 which reduced Baghdad's influence in the northern Iraq. Iraqi central government took the claim for Kurdish autonomy as undermining its power and sovereignty, while the KRG's quest for independence made any Iraqi involvement in Kurdish affairs unwanted (Nader et al., 2016).

The Kurds of Iraq are considered to be politically more organized as compared to the Kurds of other three states. KRG had a government independent of Baghdad, its own parliament, separate elections and most importantly its own military known as Peshmerga. Gunter considered that the KRG has the potential for independence in the case of failing democracy in Iraqi (Gunter, 2008).

\section{Theoretical Framework:}

The issue of Kurds in terms of right to self-determination and autonomy has been studied and understood under the theory of conflict and resolution with a focus on particular assumption drawn by Wallenstein (1945). Wallenstein (1945) presented a theoretical mechanism for conflict and resolution from Johan Galtung, Thomas Schelling and of Lewis A. Coser's work. According to him, the resource which is being disputed is being divided. In essence, this means that both opposing sides have changed their goals to some degree, allowing for some kind of "meeting the other side halfway" compromise. One of the opposing parties' interests shifts. Although it is unusual for a political party to fully change its basic positions, it may show a shift in its priorities. In this case, new conflict resolution options can present themselves. It is like horse-trading between adversarial groups. This means that one side gets their demands met on one topic and the other gets their demands met on another. The parties agree to share ownership of the disputed resource and rule together. It may be a long-term arrangement or a temporary arrangement for a transition time that, when completed, results in the conflict's wholeness. The parties agree to hand over power to a third party. The parties use dispute resolution mechanisms such as arbitration or other legal proceedings to settle their disagreements. The primary parties' consent or approve that a third party will take possession of the disputed resource in this mechanism. The parties agree to leave control to someone else. In this mechanism the primary parties agree, or accept, that a third party takes control over the contested resource. The parties use dispute resolution mechanisms such as arbitration or other legal proceedings to settle their differences. This involves devising a protocol for resolving the dispute, without the parties' immediate control.

\section{Methods and Material}

In this paper, exploratory and explanatory approaches have been used to analysis the scenario. Both historical and analytical methods are applied, since the Kurdish topic is historically deep rooted. Kurdish issue is as historical as the Middle Eastern history. Both primary as well as secondary sources have been utilized in order to get the actual picture of the issue. Meanwhile 
concerns of the state's relevant to the issue along with public views have been watched and recorded through utility of primary as well as secondary sources. Primary data included constitution of Iraq, document of Treaty of Severs, different laws and official statements by the government of Iraq and Kurdish Regional Government. While for the secondary sources, this study has used various academic articles, books, journal articles and newspaper articles in order to get the accurate view point of the historical issue.

\section{The Kurd's Struggle for an Independent State: A Discussion}

\subsection{Historical Background of Kurd Issue}

The Kurds, tribally organized nation existed in the Middle East since ancient times, they are descendant of the Iranian branch of Indo-European family (including Turkic, Armenian, Assyrian, Persian and Arabs) who settled in the Zagros Mountains mostly during the second millennium BC (McDowall, 2004). Similarly, their language also comes from the same family of the Iranian language. This mountain range is still the heartland of their main population concentration where Iran, Iraq and Turkey meet. As indicated by most analysts with practical experience in the East, this local land is the one followed back to the second human era. It was possessed from the early periods of mankind's history by the societies in the Zagros Mountains made out of the Lulu, Gutti and also the Khaldeans, the Sumerians and Hurians. Antique people from these areas form foundations of the Kurdish people (Mella, 2005). Numerous Kurds see themselves as descendent from the Medes, an antiquated Iranian people, who conquered the Assyrian capital of Nineveh in 612 BC. This date 612 BC also considered as the start of first Kurdish year famously known as Nowruz (Frye, 2012). Some historians think that they mixed with other ethnic groups after the fall of Nineveh, another group has opinion that after the Median Empire had passed its prime, the Medes pulled back into the mountains and established the stock from which sprung the Kurds of today (Hubbard, 2003).

In $7^{\text {th }}$ century, with the advent of Islam, Arabs conquered the territories of the Kurds. During that time, most of Kurds converted to Islam. Their territories were ruled by several dynasties including Seljuk, Turks, Mongols, Safavids and at the end of thirteenth century, the Ottoman. The term "Kurdistan" was first introduced by Seljuk as a geographical term in $12^{\text {th }}$ century. Further "Kurdistan" became a common name for denoting a system of Kurdish chiefdoms or minor principalities. ${ }^{1}$ Among these the famous principalities were Shaddadids (951-1075), the Marwanids (984-1083), and the Hasanwayhids (959-1095) who dominated the Zagros between Shahrizur and Khuzestan, on the east side of the Shatt al Arab (McDowall, 2004). Historically there have been several Kurd dynasties, who have ruled the Kurd territories. Among them the most famous was Ayyubids (1171-1260) founded by Salah din Al Ayyubi. Between $12^{\text {th }}$ and $13^{\text {th }}$ centuries, Ayyubids ruled a territory that extended from the Libyan coasts to the heart of Middle East, the modern areas of Syria, Lebanon, Jordan, Yemen, Mecca, Medina, and Southern Turkey. In 1171, Salah din Al Ayyubi brought end to the Egyptian Fatimid dynasty and restored the Abbasids rule. Salah din Al Ayyubi is famous in West for defeating the crusaders armies in battle to recapture the Holy city of Jerusalem in 1187 during battle of Hattin (Paolo Magri, 2016).

With the expansion of Ottoman Empire in sixteenth century Kurds were integrated into the Ottoman Empire along with the Safavid dynasty in Persia. During the rule of Ottomans and Safavids, Kurdistan became a buffer region in many wars to gain the influence in the region. 
In 1514, when Sultan Suleiman of Ottoman Empire the $1^{\text {st }}$ defeated the Shah of Persia, prominent Kurdish diplomat Idris Bitlisi played significant role in establishing the treaty between Kurds and Ottomans. He persuaded the Sultan to give back former rights and privileges of the Kurds principalities, in exchange for their commitment to protect the border between Ottomans and Persia. Under the Ottoman rule, there were two major tribes who represented the Kurds-Babans and Ardalan. The city of Sulaimaniya was founded by Babans. At the end of $19^{\text {th }}$ century, controlling the land of Kurds got international momentum due to the entrance of political and military interests of major foreign powers of that time. In the Russo-Turkish war (1877-78), strategically these territories were considered to be very important due to their cross-border nature. These territories were subject to interference by the European powers for because of clash between Kurds and Armenians and its threat to Christian minorities in the region (McDowall, 2004).

With the start of First World War, the British government along with allied powers used Kurds against the Ottomans giving a hope for the Kurdistan. Further U.S. President Woodrow Wilson in his fourteen points mentioned that "that non-Turkish minorities of the Ottoman Empire should be granted the right of autonomous development" (Durham, 2010). This promise was addressed by the Europeans after the world war when "Treaty of Severs" was signed in 1920. Article 62 of this treaty provides "a commission sitting at Constantinople and composed of three members appointed by the British, France and Italian governments respectively shall draft within six months coming into force of the present Treaty a scheme of local autonomy for the predominantly Kurdish areas lying east of the Euphrates, south of the southern boundary of Armenia as it may be here after determined, and north of the frontier of Turkey with Syria and Mesopotamia" (Elphinston, 1946, p. 87 ). Such hopes were shattered three years later when the Treaty of Lausanne 1923 was signed setting the boundaries of modern Turkey and leaving no provision for a Kurdish state. This legitimized Kurds with minority status in their respective countries. The Kurds were divided among the states of Turkey (southeast), Iran (northwest), Iraq (north) and Syria (northeast).

\subsection{Political Struggle of Iraqi Kurds}

At the end of First World War, the British armed forces occupied the former Ottoman provinces of Basra and Baghdad which are at present southern and central regions of Iraq. With the ceasefire between the allies and Ottoman Sultan, Britain additionally took up control of the Mosul region - currently the northern Iraq. Britain appointed a popular Kurdish leader of the region Sheikh Mahmud Barzanji in 1919 as the governor of Sulaymaniya with an intention to control the control the southern region of Kurdish majority population (Dahlman, 2002). He declared himself as the King of Kurdistan (Tripp, 2000). In 1920, he started rebellion against the British. But he was not successful. He was captured and imprisoned. The assurance of autonomy and self-determination in Treaty of Severs for Kurdish was abrogated in the renegotiated bargain with Mustafa Kemal in 1923. After suppression of unrest, the rapid objective of Britain was to choose another colonial administrative framework to control Basra, Baghdad and Mousal. The British enthroned an Arab king, Emir Faisal (Vanly, 1980). In June 1930, Anglo-Iraqi treaty ended the British mandate system and recognized the ceremonial independence of the Iraq. The Suleimanieh district promptly rose up in protest under Mahmoud Berenzendji which was smothered by British air and ground troops. With the final defeat of Sheikh Mahmoud in 1931, Mulla Mustafa Barzani emerged as a prominent leader and continued the Kurdish struggle. He was the guiding spirit of the Kurdistan political party (KDP) founded on 16 August 1946 in Iran. 
In 1961, there was a revolt (Aylul Revolt) against the Iraqi government led by Mustafa Barzani in an attempt to establish autonomous Kurdish government in Northern Iraq. The war was ended after agreement was negotiated on March 1970 known as Iraqi-Kurdish Autonomy Agreement. Theoretically it provided autonomy to the Kurds (Gunter, 2003). During the revolution, Mulla Mustafa resume its relations with Israel, and in the 1967 Arab-Israel war, Mustafa's Peshmerga attacked government in order to distract Iraq from the Israeli front. In exchange Mustafa received US \$ 50,000 from Israel (McDowall, 2004). Since 1961, there had been an estimated 60,000 casualties, over 3,000 villages in Iraqi Kurdistan seriously damaged. Kurdish Democratic Party was enjoying support from Iran and United States. But "Algiers Agreement" in 1975, supported by United States and signed by the Iran and Iraq to settled their land dispute, made Iran end its support for the KDP. This agreement led to the defeat of Mustafa Barzani. He was granted asylum in U.S. where he died in 1979. After his death, his son Masood Barzani became the leader of KDP.

Another factor that led to the defeat of Mustafa Barzani was the intra-Kurdish conflict. Example of such internal division and tension was breaking tie between leader Ibrahim Ahmed and his son in-law Jalal Talabani and Barzani in 1964. As a consequence, separate political party named 'Patriotic Union of Kurdistan' (PUK) was established. Kurdish Democratic Party and Patriotic Union of Kurdistan remained dominant political parties in Iraq. Their basic differences were based on leadership, control over revenue and ways of dealing with the central government. KDP was strong in the tribal mountainous northern areas bordering with Turkey and PUK was dominant in southern Kurdish areas along with Iran.

To strengthen the Iraqi government's control on the Kurdish areas and to create the security belt- along with the Iranian and Turkish border to stop their future interference, Iraqi government widened width of border from $5 \mathrm{~km}$ to $30 \mathrm{~km}$. As a result, 1400 Kurdish villages were erased, at least 6,00000 peoples were deported to resettlement camps and rest were sent to the southern Iraqi provinces Diwaniya, Nasiriya and Afak. Further the government took steps to settle the demographic balance in disputed areas and replaced Kurdish families in the disputed districts of Khaniqin, Kirkuk, Mandali, Shaykhan, Zakhu with Iraqi Arabs and Egyptians (McDowall, 2004).

Moreover, the first Gulf War between Iran and Iraq led to genocide of Kurds. As the war broke out, Baghdad put its effort to accommodate the Kurds to persuade them not to assist Iran. In 1984, PUK agreed on ceasefire with government, but KDP remained in rebellion and assist Iran to capture Hajj Umrah. One of the western diplomats considered it "a stab in the back that Saddam will never forget" (McDowall, 2004, p. 348). In response, Saddam Husain took revenge against the Barzani clan. Almost 8,000 Barzani males were captured, dragged in the streets and executed. In the words of Saddam Husain - "they went to Hell". Additionally, in 1988, Iraqi forces launched two lethal gas attacks on Kurdish town of Halabja killing 5000 Kurds. The 'Anfal' (Spoils) operation took 200,000 Kurdish lives.

The spread of Saddam's genocide made both the Kurdistan Workers' Party, PKK and PUK continued their guerrilla attacks. In March 1991, the Kurdish insurgency was crushed. Saddam's troops recaptured all the Kurdish territories and around 1.5 million Kurds abandoned their homes. Their immediate destiny was Turkey and Iran as refugees. However, Turkey closed its borders and Iran allowed around 1 million refugees (Dahlman, 2002). In such situation, the United States led coalition was created against Iraq in response to Saddam's 
attack on Kuwait. In spite of having concerns that making an internationally administered territory inside Iraq might disregard standards of state sovereignty, the United Nations Security Council adopted Resolution 688 accommodating a safe haven around Dahuk in northern Iraq (Brown, 1999). Finally, the establishment of safe heaven and creating no fly zone prohibited the Iraqi planes from flying north of $38^{\text {th }}$ parallel and ended the decade of suppression of Kurds in the north.

Hence three western powers intervened and instituted a no-fly zone in the Kurdish areas to protect the civilians from air strikes of Iraqi military and made the refugee return. Thus, the conflict between Iraq's central government and Kurds was internationalized. Soon after internationalization of the struggle of the Kurds, Barzani and Talabani once again opened the room for negotiations over autonomous region. The Kurds demanded for the annexation of Kirkuk, Khaniqin, Mandali and introduction of multi-party democracy which were unacceptable to Baghdad (McDowall, 1996). On the other hand, Kurds also denied the demand to cut-off foreign contacts and assistance. By mid of the 1992, Peshmerga captured Dahuk, Arbil and Sulaymaniya and held elections. PUK and KDP formed coalition government, famously known as Kurdish Regional Government. This election enhanced the concerns of the other three pawns of the chess and further split the Kurds. Intra-Kurdish civil war broke out over the tribal lands of dispute. As a result, KRG divided into Arbil controlled by KDP and Sulaimaniya under PUK. However, in 1998, United States induced the two parties into a formal agreement known as Washington Agreement (Makovsky, 1999).

The turmoil resulting from USA's invasion of Iraq in 2003, provided Kurds an opportunity to come in front. They participated equally along with Iraqi Arabs in the United States led coalition government and emerged as a major de facto state in the region. Additionally, in 2005 new constitution of Iraq was enforced after referendum and Iraq became a federal state consisting on Regions and Governorates. The Kurdistan Regional Government (KRG) was recognized as a federal region with its own institutions including regional government internal armed forces (Peshmerga), parliament and president. The constitution recognized Kurdish and Arabic Language as an official language of Iraq and also allowed the regional government to form their own military to secure I borders and legalize the existence of Peshmerga (Washington Post, 2005). Moreover, Jalal Talabani became the President of Iraq and Barzani gained the presidency of KRG.

Furthermore, the 2013 elections brought many changes in the politics of Iraqi Kurds, along with KDP and PUK. Another political party was also came in front Gorran (a movement for change). It is led by Nechirvan Mustafa former PUK leader who left the party in 2006. Out of 111 seats of Kurdish National Assembly, 38 won by KDP, Gorran 24 and PUK 14, remaining 17 seats were won by different parties. According to the constitution 58 seats were needed to form government, but no single party won 58 seats (NDI, 2013). Coalition government was formed and designations were divided among three major parties. Nechirvan Barzani as Prime Minister was from KDP, Qubad Talabani as Deputy Prime Minister was from PUK and Yousef Muhammad as Speaker of Parliament was from Gorran. The contention between KRG and central government over the fulfilment of constitutional rights led the Kurds to think about the independence referendum in Kurdish majority provinces.

\subsection{Referendum for Independent State}

Despite huge opposition from national, regional and international states, Iraqi Kurds conducted 
referendum for their Independent state on 27 September 2017. According to Iraqi Kurds "the time has come to end the forced marriage with Iraq" (Rasheed, 2017). They believed that central government is failed to conduct referendum in the disputed territories of Kirkuk and adjacent areas. Although the announcement for independence referendum was made by Barzani in 2014, due to the security threats from Islamic State (IS) he agreed to delay the referendum. But as the Iraqi federal Government declare the victory over IS in July 2017, the Barzani decided that time has come for referendum. Additionally, Kurds played very significant role in fighting with IS. They believed that the Iraqi Federal Government failed to secure its own territory. They considered "that being part of One Iraq is not affordable business for Kurds" (Rasheed, 2017).

\subsection{KRG's Relations with Iraqi Central Government}

KRG was established under the protection of western coalition. To weaken this regime, Baghdad imposed blocked on the Kurdish region. The region faced severe shortage of foodstuff, oil and other things. During Saddam Hussan's era, relation between KRG and central government was not good. The progressive relations were developed in post Saddam period, with the US sponsored coalition government. The 2005, constitution accommodated all the Kurdish issues. But it lacked implementation of the provisions of the articles which created tension between KRG and Baghdad. The major issues included ownership over natural resources and management, role of Peshmerga, control of revenue, and the final status of disputed territories (Gunter, 2008, p. 55).

Major territorial dispute was related to the province of Kirkuk which some of the observers considered as a key to Kurdish independence. Because Kirkuk had oil reserves that could give the Kurds financial resources for independence. As indicated by the Iraqi constitution, the Kirkuk status referendum intended to be passed not later than December, 31, 2007. This referendum was supposed to decide whether it would be in the region of KRG or not. However, it has not been held at this point (Iraq, 2005).

The region's oil export and its revenue are another source of contention between regional government and Baghdad. The conflict over oil has dominated government's relations with KRG for decades. Kurdish warriors blocked ISIS from captivating Kirkuk in 2014, at the same time controlled the close-by oil fields. The two governments were totally dependent on oil. In 2016, oil represented 85 percent of central government revenue, and on the other hand, KRG's major and only source of revenue came from oil (Snow, 2018). In the wake of 2017 referendum, central government cut down half of oil production from Kirkuk oil fields under KRG which left KRG in miserable situation. Tracing of border "Green Line" between Arab Iraq and Kurds also contributed to the unhealthy relations between these two (Park, 2014).

After the United States military withdrawal from Iraq, relations between Erbil and Baghdad became shoddier. The prime minister of Iraq Nouri al-Maliki (2006-2014) was blamed for ignoring the settlement of Kirkuk and other adjacent disputed territories. Further he cut the salaries of KRG's employees and adopted many racial policies to put Kurds on their knees. On the other hand, Maliki stressed that KRG was providing safe heaven to escaped Ba'athists and Erbil violated the Iraqi constitution by selling oil independently which affected the Iraqi economy (Salih, 2019). 
The collapse of military cooperation between Erbil and Baghdad created security vacuum which gave chance to the Islamic State (IS) to fill in 2014. IS extended its power over the 40 per cent of the Iraqi territory. After liberating Mosul from Islamic State in 2017, Erbil conducted independence referendum. But due to the lack of support from regional and international actors, it was not possible to pursue strong decisions further.

\subsection{Regional Implications of Kurdish Independence Referendum}

The establishment of Iraqi Kurdistan have trapped the neighbours of Iraq in a rock and hard situation as far back as a Westerns forced no-fly zone over northern Iraq in 1991. The two predominant political parties - the KDP and PUK could build up their own self-governing region, with its very own political framework, administrations, and foreign relations. The formation of KRG had great impact on the nationalistic movement of Turkey, Iran and Syrian Kurds. Though the goals of Kurds in these areas were different from each other, the ultimate goal was $t$ establishment of separate state. The emergence of KRG gave push and new dimension to the neighbouring Kurds. Since then, any major change in the Iraqi Kurdistan have direct implications on the states sharing Kurdish population.

The establishment of Kurdish region and elections caused uneasiness among the neighbouring countries with Kurdish population. Iran and Turkey strongly rejected any type of selfgovernment for the Kurds. In the meantime, the coalition additionally expected that elected assembly might demonstrate an initial move towards a declaration of independence state for Kurds. Therefore, they refused to recognise new Kurdish assembly and Kurdish Regional Government (McDowall, 1996).

Turkey has the biggest Kurdish population. Since the collapse of the Ottoman Empire, Mustafa Kemal and his successors utilized the state apparatus to suppress all the ethnic groups including Kurds and assimilated them in the secular Turkey in the name of Turkification. Turkey perceived the possibility of a separate independent Kurdistan to be "an existential threat to Turkey's own internal stability" (Nader, Hanauer, Allen, \& Scotten, 2016). They thought that the creation of independent Kurdish region would be a safe haven to its Kurdish militants. That is why, they started military campaigns in northern Iraq throughout 1990s.

To Turkey, an autonomous Kurdish region was fuel to its internal rebellion. Initially, Turkey opposed any type of progress related to Iraqi Kurds that in future might lead towards an independent Kurdistan. However, in post Saddam period, change occurred in the policy of Turkey toward Kurds. According to Tocci, "Relations between Turkey and Northern Iraq have evolved at a breath-taking pace, with Turkish policies currently bolstering the KRG's drift towards independence, a prospect considered unthinkable in Ankara only a few years ago" (Tocci, 2013).

Later, Ankara not only established good relations with Iraqi Kurds but also made policy measure to resolve its Kurdish conflict known as Kurdish opening. Though Turkey cooperated with KRG's leaders to counter and manage the Kurdish issue, it has strongly opposed the initiative of referendum by the KRG. The official statement released by Ankara stated that "The illegitimacy of the referendum... and its being unacceptable were once again specified. It was strongly stressed that this step, which directly threatens Turkey's national security, was a grave mistake that threatens Iraq's political unity and territorial integrity as well as peace, security and stability of the region" (Press TV, 2017). However, Iran's perception has been that 
if any Kurdish independent state would emerge in the region, Turkey will be benefited more than any other state. Iran was anxious about the pan-Turkish ideology in Azerbaijan and considered Erbil-Turkish relations as expansion of Turkey or Neo-Ottomanism for revival of Ottoman Empire.

Iran was the first state where modern Kurdish state Mahabad Republic (1946) emerged under the protection of Soviet Union. But it failed. Since the Islamic revolution in Iran 1979, they have adopted a policy of killing the leaders of Kurds in their country. They believed that "a leaderless movement would take long time to reorganize" (Bengio, 2017, p. 35). This policy helped Iranians manipulating their Kurdish struggle successfully. However, political struggle by the Kurdish political parties (KDP-I, Komala, PJAK) continued in Iran. In 2012, the KDPI and Komala signed an agreement calling for the toppling of Iranian government, establishment of federal government and separation of religion from polices (Bengio, 2017). However, it has not materialized yet.

Moreover, Iran strongly opposed the Kurd independence referendum in Iraq and stressed that such move could destabilise Iraq internally, as well as other countries of the Middle Eastern region. The Iranian officials met with the Turkish and Iraqi counterparts to reportedly take some joint measures, such as trade sanctions, and increase military cooperation against the Kurdish administration in northern Iraq. Moreover, in a solidarity with Iraq, Tehran conducted joint military drills with the Iraqi military between the Iraqi and Iranian Kurdish border (Washington Post, 2017).

The Syrian Kurds participated in the guerrilla insurgency with PKK against Turkey during 1990s. When it comes to the political dimension, they are more follower of KDP's politics in norther Iraq. With the outbreak of civil war in Syria in 2011 and power vacuum created after the withdrawal of Syrian forces from Kurdish majority territories, they announced internal autonomy just like Iraqi Kurdish Region. In November 2013, the PYD (Partiya Yekîtiya Demokrat -Syrian branch of PKK) unitarily declared autonomy for the three cantons of Afrin, Kobane and Jazire officially known as Rojava.

\section{Conclusion}

The nature of Kurdish struggle in different states has different aspects with a common goal to have right to self-determination. In the multifaceted medley of unresolved problems in the Middle East, the Kurdish question no doubt is one of most complex and difficult issue. Predicting the future of Kurds is not easy as there are number of variables and actors determining the outcome including number of diverse Kurdish political groups the states in which they are residing (Turkey, Iraq, Syria and Iran) and more importantly, the role of international actors like the United States. The entrance of ideological based non-state actors (like Islamic State, Islamist groups, ethnic groups Turkoman, Assyrian, etc.) in Kurdish territories in recent years also gave the Kurds tough time. The idea of nation state system of Kurds poses a challenge to the core attribute of territorial integrity of the states where they reside. As a result, even if the Kurds have been successful in pursuing autonomy to some extent in Iraq, overall, their struggles in four countries of residence remain a continuous challenging process for right to self-determination. Their endeavours for autonomy in Iraq have been subject to regional threat due to its potential for inviting more divides and rebellion from Kurds in different countries. They have been denied from their rights on different excuses of 
vested political interests in national, regional and international level that were beyond the control of a single variable.

It should be considered that the Middle East has already became the battle ground for various regional and international actors. In such situation, continuing the policy of suppression of Kurds in coming future may become another major factor of instability in the region. Kurd's struggle for self-determination should be considered with due consideration for the greater purpose of peace and security in this region.

\section{References}

Alaaldin, R. (2017, September 19). Regional implications of the Kurdish independence vote. Aljazira. https://www.aljazeera.com/indepth/opinion/regional-implications-kurdishindependence-vote-170918123748896.html

Bayat, K. (2008). Iran and Kurdish Question. Middle East Report (247), 28-35.

BBC. (2017, October 21). http://www.bbc.com/news/world-middle-east-29702440

Bengio, O. (2017). The Kurds in a Volatile Middle East. Mideast Security and Policy Studies, (130), 1-54.

Bidlisi, S. K. (2005). The Sharafnama, or, The history of the Kurdish nation, 1597. (M. R. Izady, Trans.) Mazda.

Brown, S. G. (1999). Sanctioning Saddam: The Politics of Intervention in Iraq. I. B. Tauris.

Bruinessen, M. V. (1992). Agha, Shaikh and State: The Social and Political Structures of Kurdistan. Zed Books.

Cabinet, K. (2010, Jun 27). Kurdistan's history until the 19th century. Kurdistan Regional Government. http://cabinet.gov.krd/a/d.aspx?s=010000\&l=12\&a=18686

Chaliand, G. (1980). People Without a Country: The Kurds and Kurdistan. Zed.

Connelly, H. H. (2017). Kurdistan's Struggle for Sovereignty: State, Societal, and Human Security. Arab Center for Research and Policy Studies, 13.

Dahlman, C. (2002). PoliticalGeography of Kurs. Eurasian Geography and Economics, 271299.

Dahlman, C. (2002). The Political Geography of Kurdistan. Eurasian Geography and Economics, 43(4), 271-299. https://www.tandfonline.com/doi/pdf/10.2747/15387216.43.4.271

Disney, D. B. (1980, December). The Kurdish Nationalist Movement and External Influences. Naval Postgraduate School. https://calhoun.nps.edu/handle/10945/17624

Durham, W. D. (2010). The 1920 Treaty of Sevres and the struggle for a Kurdish Homeland in Iraq and Turkey between world war. College of the Oklahoma State University .

Elphinston, W. G. (1946, January ). The Kurdish Question. International Affairs (Royal Institute of International Affairs 1944), 22(1), 91-103. https://www.jstor.org/stable/3017874?seq=1\#metadata_info_tab_contents

Frye, R. N. (2012, March 29). IRAN v. PEOPLES OF IRAN (1) A General Survey. Encyclopaedia Iranica. http://www.iranicaonline.org/articles/iran-v1-peoples-survey

Gunter, M. (2008). The Kurds ascending: the evolving solution to the Kurdish problem in Iraq and Turkey. Palgrave Macmillan.

Gunter, M. M. (2003). The A to Z of the Kurds. United Kingdom: Scarecrow.

Gunter, M. M. (2008). The Kurds Ascending: The Evolving Solution to the Kurdish Problem in Iraq and Turkey. Palgrave Macmillan. 
Hubbard, G. E. (2003). From The Gulf to Ararat: An Expedition Through Mesopotamis and Kurdistan. Asian Education Services.

Iraq, R. o. (2005, October 15). Constitution of the Republic of Iraq. Refworld. https://www.refworld.org/docid/454f50804.html

Kurdistan's history until the 19th century. (2010, July 27). Kurdistan Regional Government. http://cabinet.gov.krd/a/d.aspx?s=010000\&l=12\&a=18686

Makovsky, A. (1999, September 29). Kurdish Agreement Signals New U.S. Commitment. The Washigton Institue. $\quad$ https://www.washingtoninstitute.org/policyanalysis/view/kurdish-agreement-signals-new-u.s.-commitment

McDowall, D. (1996). The Kurds. Minority Rights Group.

McDowall, D. (2004). Modern History of Kurds. I. B. Tauris.

Mella, D. J. (2005). Kurdistan and the Kurds a Divided Homeland and a Nation without State. Western Kurdistan Association.

Nader, A., Hanauer, L., Allen, B., \& Scotten, A. (2016). Regional Implications of an Independent Kurdistan. The RAND Corporation.

NDI. (2013). Iraq Election Watch: KRG Parliamentary Elections. National Democratic Institue. https://www.ndi.org/sites/default/files/NDI-Iraq-Election-Watch-Ed7.pdf

Paolo Magri, E. b. (2016). Kurdistan An Invisible Nation. ISPI.

Park, B. (2014). Turkey-Kurdish Regional Governmnet Relations After the U.S Withdrawal From Iraq: Putting the Kurds in Map? U.S. Army War College.

Press TV. (2017, September 23). Iraqi Kurdistan vote poses direct threat to Turkish national security. $\quad$ https://www.presstv.com/Detail/2017/09/23/536162/Turkey-NationalSecurity-Council-Iraq-Kurdistan-referendum-national-security-threat

Press TV. (2017, September 23). Iraqi Kurdistan vote poses direct threat to Turkish national security. https://www.presstv.com/Detail/2017/09/23/536162/Turkey-NationalSecurity-Council-Iraq-Kurdistan-referendum-national-security-threat

Rasheed, A. (2017, September 29). The Kurds desperately want freedom - why won't the free world support them? The Guardian. https://www.theguardian.com/commentisfree/2017/sep/29/kurdish-freedomreferendum-iraq

Salih, D. (2019, Feburary 27). The Kirkuk Case and Baghdad-Erbil Relations. The London School of Economics and Political Science. https://blogs.lse.ac.uk/mec/2019/02/27/the-kirkuk-case-and-baghdad-erbil-relations/

Salman, R., \& Mahmoud, M. (2014, July 11). Kurds seize Iraq oilfields, ministers pull out of government. Reuters. https://www.reuters.com/article/us-iraq-securitypolitics/kurds-seize-iraq-oilfields-ministers-pull-out-of-governmentidUSKBN0FG0R520140711

Sam-Wilkin, D. M. (2017, March 9). Why Kurdish Oil Is a Wild Card for Markets. Bloomberg. https://www.bloomberg.com/news/articles/2017-03-08/why-kurdish-oil-is-a-wildcard-for-markets-quicktake-q-a

Snow, A. (2018, January 30). Kurdistan and Baghdad: A Tangled Web Over Oil and Budgets. United States Institue of Peace. https://www.usip.org/publications/2018/01/kurdistan-and-baghdad-tangled-webover-oil-and-budgets

Tocci, N. (2013). Turkey's Kurdish Gamble. The International Spectator, 48(3), 67-77. https://www.tandfonline.com/doi/full/10.1080/03932729.2013.814997?scroll=top\& needAccess $=$ true

Tripp, C. (2000). A History of Iraq. Cambridge University. 
Vanly, I. S. (1980). Kurdistan in Iraq. In G. Chaliand, \& G. Chaliand (Ed.), People Without a Country: The Kurds and Kurdistan (pp. 153-210). Zed.

Washington Post. (2005, October 12). Full Text of Iraqi Constitution. Washigton Post. http://www.washingtonpost.com/wpdyn/content/article/2005/10/12/AR2005101201450.html

Washington Post. (2017, October 10). Iran Flexes Its Muscles After the Kurdish Referendum. The Washigton Post. https://www.washingtoninstitute.org/policy-analysis/view/iranflexes-its-muscles-after-the-kurdish-referendum

\section{Note:}

${ }^{1}$ McDowell has also pointed out; it is more than a geographical term as it also refers to a human culture that exists in the region: "to this extent Kurdistan is a social and political concept". 